\title{
ШЛЯХИ ПІДВИЩЕННЯ РЕАЛІЗАЦІї СОЦІАЛЬНИХ ПРОГРАМ У ГРОМАДСЬКОМУ ЗДОРОВ'ї
}

\author{
Тернопільський національний медичний університет \\ імені І. Я. Горбачевського МОЗ України, м. Тернопіль, Україна
}

\begin{abstract}
Мета: дослідити чинники, які сприяють успішному впровадженню і виконанню програм у галузі громадського здоров'я та розширенню сфрер їх застосування.

Матеріали і методи. У процесі дослідження використано загальнонаукові та спеціальні методи: теоретичного узагальнення, метод порівняльного аналізу, класифікації і групування, статистичного порівняння та узагальнення.

Результати. Фахівці, які працюють у галузі громадського здоров'я, допомагають у покращенні здоров'я окремим категоріям людей та громадам. Найбільшою силою громадського здоров'я $€$ його особлива спрямованість на максимальне покращення здоров'я, щоб суспільство могло досягти найзаповітніших цінностей: щоб діти народжувалися і росли здоровими, студенти були здоровими та могли вчитися, працівники були здоровими та продуктивними, а люди похилого віку старіли гідно. Переконливі дані та докази дій, широкі коаліції та ефективна комунікація породжують та підтримують політичні зобов'язання, необхідні для успішних дій в галузі громадського здоров'я. Для поліпшення програм охорони здоров'я часто важливо виділити тягарі хвороб та їх наслідки для здоров'я. Також корисно наводити реальні приклади людей, яким завдано шкоди через бездіяльність або які отримали користь від конкретних програм. Ефективні об'єднання з ключовою підтримкою і керівництвом окремих осіб та позаурядових груп часто мають важливе значення для прогресу.

Висновки. Ефективне та скоординоване об'єднання політичного, технічного і управлінського керівництва може збільшити ймовірність реалізації програм, що захищають та покращують здоров'я населення.

Для подальшого успішного розвитку регіональних/місцевих соціальних програм є необхідним запровадження інноваційних підходів до просрілактично-оздоровчих заходів; впровадження методології оцінки медико-екологічних ризиків; запровадження стандартизованих уніфікованих скринінгових методів щодо виявлення контингентів ризику.

На державному рівні необхідно створити систему регулювання регіональних/місцевих соціальних програм та впровадити комплексні заходи щодо звітності, стандартизації, моніторингу.
\end{abstract}

КЛЮчОВІ СЛОВА: громадське здоров'я; соціальні програми; інновації; комунікація; політична прихильність; управління.

Соціальні програми у галузі громадського здоров'я покликані впроваджувати заходи, спрямовані на профрілактику захворювань, збільшення тривалості та якості життя і готовність до надзвичайних ситуацій [3, 4].

Обмеження фрінансування, фрормальний процес моніторингу, відсутність співпраці неурядових установ, місцевих і національних організацій громадянського суспільства та організацій приватного сектору $€$ передумовами до занепаду виконання соціальних програм у галузі охорони здоров'я. Формування інноваційної основи системи соціальних програм громадського здоров'я, стратегії їх планування можуть бути успішними, використавши певні пропозиції $[1,2]$.

Мета роботи: дослідити чинники, які сприяють успішному впровадженню і виконанню програм у галузі громадського здоров'я та розширенню сорер їх застосування.

Матеріали і методи. У процесі дослідження використано загальнонаукові та спеціальні методи: теоретичного узагальнення, метод порівняльного аналізу, класифрікації і групування, статистичного порівняння та узагальнення.

Результати дослідження та їх обговорення. Соціальні програми у галузі громадського

(с) Н. О. Кравець, 2021 здоров'я стають успішними та «виживають», якщо організації та коаліції вирішують шість ключових завдань: інновація для розробки доказової бази дій; технічний пакет обмеженої кількості високопріоритетних, основаних на фрактах, втручань, які разом матимуть позитивний вплив; ефективне управління діяльністю, особливо за допомогою суворого моніторингу, оцінки та вдосконалення програми в режимі реального часу; партнерства та коаліції з державними і приватними організаціями; надання точної та своєчасної інформації спільноті охорони здоров'я, особам, які приймають рішення, і громадськості 3 метою залучення громадянського суспільства; політичне зобов'язання - отримати ресурси і підтримку для еорективних дій. Для прикладу, програми викорінення віспи, боротьби з туберкульозом, боротьби з тютюнокурінням, знищення поліомієліту та інші досягли успіху, вирішивши саме ці ключові завдання.

Обмежене та нестабільне фрінансування, відсутність автоматичних засобів для відстеження і підвищення ефективності роботи, малочисельна робоча сила та недостатня політична прихильність - все це може призвести до зриву соціальних програм охорони здоров'я. Впровадження може бути успішним і стійким, якщо організації 
та коаліції ефективно вирішують шість вищевказаних пропозицій. Цю концепцію можна проілюструвати на прикладі роботи колеса, де інновації як центральний вузол, що забезпечує його рушійну силу та підтримку інших елементів: технічного пакета, управління, партнерства та комунікації. Ці елементи, в свою чергу, утримуються разом завдяки політичній прихильності, що забезпечує необхідну силу для прогресу.

Інновації мають важливе значення для всіх аспектів розробки програм охорони здоров'я та доказової бази, необхідної для встановлення та вдосконалення технічних елементів і успішного їх впровадження. Нова діагностична методика, лікування або вакцина можуть зробити можливою недосяжну раніше мету. Нові мікробні технології геномного секвенування та біоінформатики дозволяють виявити спалахи, яких ми не можемо побачити в даний час, і запобігти та зупинити розповсюдження інсекційного захворювання. Інновації не повинні обмежуватися тільки наукою чи медициною, а використовуватися в інформаційних системах, зборі даних, комунікаційних техніках та фрормуванні питань, які можуть збільшити політичну прихильність, і мати важливе значення для прогресу. Вони можуть допомогти вдосконалити управління програмами для їх розширення і розповсюдження. Наприклад, віспа була ліквідована шляхом постійного впровадження інновацій, включаючи нові організаційні методи, способи виявлення випадків, групи та вакцинації.

Найефективніші програми охорони здоров'я базуються на технічному пакеті, що фрормується з фрактичних даних: вибраній групі відповідних спільних заходів, які дозволять досягти та підтримати суттєві, а іноді й синергетичні вдосконалення конкретного фрактора ризику чи результату захворювання. Технічний пакет перевірених втручань загострює та зосереджує увагу на тих питаннях, які дозволяють здійснити конкретні дії, що $є$ ефективними. Це дає змогу уникнути розгорнутого підходу з використанням великої кількості втручань, більшість з яких має лише незначний вплив. До прикладу, стратегія лікування під безпосереднім контролем (ЛБК) для боротьби 3 туберкульозом має лише п'ять компонентів: стійке політичне та фрінансове зобов'язання, добра лабораторна діагностика, стандартизоване лікування, яке проходить під безпосереднім спостереженням, стабільне постачання високоякісних протитуберкульозних препаратів та суворий моніторинг, оцінка та підзвітність за результатами кожного пацієнта. За майже два десятиліття 3 часу широкого прийняття стратегії ЛБК було успішно проліковано понад $56 \mathrm{Mлн}$ людей і врятовано 22 млн життів. За відсутності ВІЛ ЛБК може зменшити рівень захворюваності на активний туберкульоз приблизно вдвічі. Пакет BOO3 MPOWER для боротьби з тютюнокурінням складається 3 таких заходів політики, як: моніторинг вживання тютюну і політики запобігання його використанню; захист людей від тютюново- го диму; пропонування допомоги при відмові від вживання тютюну; попередження про небезпеку тютюну; введення заборон на рекламу, промоцію та спонсорство сигарет і підвищення цін на них.

Для багатьох програм охорони здоров'я їх реалізація $\epsilon$ проблемою управління. Навіть, якщо існують політичні зобов'язання, ресурси та технічний пакет, ефективного управління може не бути.

Управління діяльністю в галузі охорони здоров'я $є$ особливо складним на відміну від приватного сектора, де такі показники, як продаж продукції, забезпечують швидкий зворотний зв'язок.

Часто не існує автоматичного, точного та доступного способу відстеження результативності програм охорони здоров'я в режимі реального часу. Крім того, вплив програм охорони здоров'я може не бути очевидним протягом місяців або навіть років, що ще більше ускладнює ефект результативності.

Ефективні програми охорони здоров'я вимагають точних, своєчасних інформаційних систем для нагляду за захворюваннями чи факторами ризику та їх реалізацією. 3 цієї причини кожен ефрективний технічний пакет включає системи спостереження та інфрормації, які можна підтримувати і надавати точну, просту, своєчасну та критичну інфрормацію про впровадження програми та її вплив у перспективі.

Суворий моніторинг та оцінка 3 механізмами уникнення упередженості даних або невпевненості в ефективності програми є важливими як для прогресу, так і для забезпечення постійності. Чесна та прозора оцінка є критично важлива для постійного вдосконалення стратегії та реалізації програми. Особливо важливим для програм, які досягли певного прогресу, $€$ уникнення самозадоволення.

Найімовірніше будуть корисними найпростіші системи, керовані чітким розумінням вимог та обмежень основних елементів даних. Одним із прикладів такої системи є реєстр хворих на туберкульоз, який ведуть в підрозділах охорони здоров'я майже у всіх країнах. Ці реєстри відстежують результати кожного пацієнта, який розпочав лікування, і не вимагають великих вкладень в інформаційні технології управління людськими ресурсами в галузі охорони здоров'я.

Охорона здоров'я стає все складнішою, причому ключові ролі відіграють партнери 3 державного та приватного секторів, які мають вирішальне значення для підтримки і поліпшення стану здоров'я населення. Важливе значення для прогресу мають коаліції. Залучення багатьох організацій до співпраці може бути повільним і незручним, але часто $€$ вирішальним для створення пропагандистської діяльності, необхідної для підтримки бюджетних, законодавчих чи регуляторних змін та реалізації нових або вдосконалених програм. Державні програми матимуть успіх і будуть підтримуватись тоді, коли неурядові організації захищатимуть їх. Партнери 
можуть доповнювати наявні людські або фрінансові ресурси, а також підтримувати та здійснювати критичні заходи. Школи, підприємства, правоохоронні органи, транспорт, сільське господарство та багато інших секторів суспільства можуть зробити значний внесок у програми та пріоритети в галузі охорони здоров'я і отримати від них велику користь. Ефективне партнерство між установами на різних рівнях управління іноді важко встановити та підтримувати. Наприклад, розподіл ресурсів та обов'язків між державними і місцевими управліннями охорони здоров'я може бути політично напруженим та складним. Дослідження стійкості громадських об'єднань у галузі охорони здоров'я свідчать про те, що прийняття колективної відповідальності й взаємної підзвітності, фрормулювання спільної місії та бачення спільних цілей можуть утримувати урядових і неурядових партнерів у координації та уникати конкуренції між ними. Можуть виникати етичні проблеми щодо розвитку державно-приватного партнерства в галузі охорони здоров'я. Розширюються партнерські відносини між урядом і харчовою промисловістю та іншими галузями, що вирішують питання охорони здоров'я; ці партнерства можуть або сприяти подальшій співпраці, або підірвати ефективні зміни, тому їх потрібно систематично і прозоро контролювати та оцінювати. Приклади ефективних багатогалузевих партнерських відносин включають коаліції з імунізації на національному та державному рівнях, до яких залучаються такі партнери, як державні установи, громадські організації, корпорації, фонди, окремі меценати, пацієнти та волонтери. Ці партнерські стосунки будують всебічні, стійкі програми громади, які виступають за політику, що призведе до імунізації людей проти хвороб, які можна запобігти вакцинацією. Такі стосунки особливо важливі для підтримки програм у складні бюджетні часи.

Спілкування також має вирішальне значення для порятунку життя під час надзвичайних ситуацій. Однозначно, спілкування 3 особами, які реагують першими, з громадськістю та іншими групами повинно бути миттєвим та чітким, має відбуватися в режимі реального часу під час події, що швидко розвивається. Навіть, коли надзвичайні ситуації у галузі охорони здоров'я проходять повільніше, як, наприклад, під час глобального спалаху COVID-19 у 2020 р., необхідно постійно передавати нову інформацію синхронно до розгортання події як для здійснення конкретних заходів, так і для мінімізації плутанини та недовіри.

Політична прихильність ґрунтується та підтримується описаними на сьогодні компонентами, які мають вирішальне значення для забезпечення урядом міцної основи для дій. Ефективно впроваджені політичні зобов'язання надають ресурси та підтримку, необхідні для координації і впровадження та підтримки заходів 3 охорони здоров'я, включаючи зміну політики, де це необхідно.

Зміни часто суперечливі, і суб'єкти, що реалізовують програми охорони здоров'я, як правило, очолюють департаменти охорони здоров'я чи інші державні установи - можуть мати менше можливостей впливати на прийняття бюджетних та політичних рішень, ніж інші групи уряду і громадянського суспільства.

Політична прихильність може мати вирішальне значення для подолання протидії програмам охорони здоров'я з боку окремих груп інтересів, таких, як тютюнова промисловість, вона вимагає розуміння галузевих тактик, ефективного спілкування 3 усіма зацікавленими сторонами і залучення громадськості та громадянського суспільства.

Політична прихильність є необхідною умовою достатнього фрінансування.

\section{Висновки}

Ефективне та скоординоване об'єднання політичного, технічного і управлінського керівництва може збільшити ймовірність реалізації програм, що захищають та покращують здоров'я населення.

Для подальшого успішного розвитку регіональних/місцевих соціальних програм $є$ запровадження інноваційних підходів до профрілактичнооздоровчих заходів; впровадження методології оцінки медико-екологічних ризиків; запровадження стандартизованих уніфікованих скринінгових методів щодо виявлення контингентів ризику.

На державному рівні необхідно створити систему регулювання регіональних/місцевих соціальних програм та впровадити комплексні заходи щодо звітності, стандартизації, моніторингу.

Перспективи подальших досліджень полягають у проведенні оцінювання планування та фрункціонування соціальних програм громадського здоров'я запроваджених і діючих в Україні.

\section{Список літератури}

1. Запорожан Л. П. Стратегія планування соціальних програм у громадському здоров'ї / Л. П. Запорожан, Н. О. Кравець // Вісник соціальної гігієни та організації охорони здоров'я України. - 2021. - № 1. - С. 66-70.

2. Запорожан Л. П. Формування інноваційної основи системи соціальних програм у громадському здоров"ї / Л. П. Запорожан, Н. О. Кравець, Д. В. Вакуленко // Вісник соціальної гігієни та організації охорони здоров'я України. 2020. - № 3 (85). - С. 114-118.

3. Розробка та фрінансування регіональних і місцевих програм громадського здоров'я : операційний посібник [Електронний ресурс] / В. Ляшко, Н. Півень, М. Брага та ін. // Центр громадського здоров'я. - Режим доступу : httр:// phc.lg.ua/wp-content/uploads/2020/05/Operativnij-posibnik-z-miscevih-program.pdf.

4. URL : https://moz.gov.ua. 


\section{References}

1. Zaporozhan, L.P., \& Kravets, N.O. (2021). Stratehiya planuvannya sotsialnykh prohram u hromadskomu zdorovyi [Strategy of planning social programs in public health]. Visnyk sotsialnoyi hihiyeny ta orhanizatsiyi okhorony zdorovya Ukrayiny - Bulletin of Social Hygiene and Health Care Organization of Ukraine, 1, 66-70 [in Ukrainian].

2. Zaporozhan, L.P., Kravets, N.O. \& Vakulenko D.V. (2020). Formuvannya innovatsiynoyi osnovy systemy sotsialnykh prohram u hromadskomu zdorovyi [Forming an innovative basis for a system of social programs in public health]. Visnyk sotsialnoyi hihiyeny ta orhanizatsiyi okhorony zdorovya Ukrayiny - Bulletin of Social Hygiene and Health Care Organization of Ukraine, 3(85), 114-118. [in Ukrainian].

3. Lyashko, V., Piven, N., Braga, M. Ryzhkova, A., Nagornaya, I., \& Prykhodko, V. (2019). Rozrobka ta finansuvannya rehionalnykh i mistsevykh prohram hromadskoho zdorovya. Operatsiynyy posibnyk. [Development and funding of regional and local public health programs. Operating manual]. Centr hromadskoho zdorovia - Public Health Center Retrieved from: http://phc.lg.ua/wp-content/uploads/2020/05/Operativnij-posibnik-z-miscevih-program.pdf [in Ukrainian].

4. Sayt ministerstva okhorony zdorovya [Website of the Ministry of Healthcare]. moz.gov.ua Retrieved from: https://moz. gov.ua [in Ukrainian].

\section{WAYS TO INCREASE THE IMPLEMENTATION OF SOCIAL PROGRAMS IN PUBLIC HEALTH}

N. O. Kravets

I. Horbachevsky Ternopil National Medical University

Purpose: to research on the factors that contribute to the success of the implementation and implementation of public health programs and the expansion of their scope.

Materials and Methods. In the process of research the general scientific methods of research were used: historical, method of comparative analysis, and statistical groupings.

Results. Those who work in and support public health improve the health of individuals and communities. The greatest strength of public health is its singular focus on maximizing health so that society can achieve its most cherished values: that children are born healthy and grow up healthy, that students are healthy and able to learn, that workers are healthy and productive, that parents are empowered to help their children reach their full potential, that health disparities are reduced, and that people are able to age with independence and dignity.

Compelling data and evidence for action, broad coalitions, and effective communication generate and sustain the political commitment necessary for successful public health action. To improve public health programs, it is often essential to highlight unacceptable existing disease burdens, health outcomes, disparities, and threats to health. It is also useful to provide real-life examples of individuals harmed by failure to act or benefited by specific programs. Effective coalitions with key support and leadership from individuals and groups outside of government are often essential for progress.

Conclusions. Effective and coordinated integration of political, technical and managerial leadership can increase the likelihood of implementing programs that protect and improve public health. For further successful development of regional / local social programs is the introduction of innovative approaches to preventive and curative measures; introduction of methodology for assessment of medical and environmental risks; introduction of standardized unified screening methods for identifying risk contingents. At the state level it is necessary to create a system of regulation of regional / local social programs and implement comprehensive measures for reporting, standardization, monitoring.

KEY WORDS: public health; social programs; innovation; communication; political commitment; management.

Рукопис надійшов до редакції 05.08.2021 p.

\section{Відомості про автора:}

Кравець Наталія Орестівна - кандидат технічних наук, доцент кафедри медичної інфрорматики Тернопільського національного медичного університету імені І. Я. Горбачевського МОЗ України; тел.: +38(0352) 52-09-90. 